\title{
A Nonracial Craniofacial Perspective on Human Variation: A(ustralia) to Z(uni)
}

C. LORING BRACE AND KEVIN D. HUN'T

Museum of Anthropology, University of Michigan, Ann Arbor, Michigan 48109 (C.L.B.); Department of Anthropology, Harvard University, Cambridge, Massachusetts, 02138 (K.D.H.)

\section{KEY WORDS Dental measurements, Race, C scores}

\begin{abstract}
Dental and craniofacial measurements were collected for 57 samples from Asia, the Pacific, the aboriginal western hemisphere, and Europe. The craniofacial dimensions include many that are not obviously under the control of specific selective forces. Similar configurations for these in different samples should yield indications of recency of common ancestry according to the logic expressed by Darwin and evident in the relationships indicated by nuclear DNA comparisons. Dental dimensions, however, vary according to the length of time that different intensities in selective forces have been in operation. The craniofacial measurements were transformed into $\mathrm{C}$ scores and used to generate Euclidean distance dendrograms. When all the material was used to generate a single dendrogram, the European and Amerindian samples sorted into two regionally identifiable clusters, and the Asian and Pacific material sorted into the three clusters identified in separate previous studies: a Mainland Asian cluster, a Jōmon-Pacific cluster and an Australo-Melanesian cluster. Since these clusters are based on variation in traits that are basically nonadaptive in nature, no hierarchical ranking is possible. The clusters simply reflect degree of relationship. This technique holds forth the promise of producing a nonracial assessment of the relationships of all the peoples of the world, past and present.
\end{abstract}

There is a spectrum of variation in what is confusingly labeled "anatomically modern" Homo sapiens that is rarely taken into account in appraisals of human evolution in general and individual fossil specimens in particular. In tooth size alone, the difference between the average condition in Australia and that in Europe (or China) would satisfy the criterion used to indicate specific difference (Gingerich, 1974, 1979, 1980; Gingerich and Schoeninger, 1979), yet there is obviously no reproductive barrier between Australians and anybody else in the world. All living human beings are demonstrably members of the same species even though there are average visible differences between the various geographically situated populations of the world. The spectrum of variation is there, however, and it should be possible to deal with it in such a fashion that we can determine how much of it is due to differences in the intensity of specific selective forces and how much of it is due to the length of time since the groups being compared shared a common ancestor. There is almost certainly some ethnocentrism inherent in viewing the spectrum as running from Europe to Australia, but this quite literally does extend from one geographical extreme of the earth to the other, and, dentally at least, the Australian aborigines can legitimately stand for a morphological extreme in contemporary $H$. sapiens and Europeans come quite close to representing their antithesis (Brace, 1980; Brace et al., in press b).

The aboriginal inhabitants of Australia have been a continuing source of fascination for anthropologists and the general public alike ever since they were first encountered by itinerant Europeans almost 400 years ago. With the addition of an evolutionary perspective developed by Charles Darwin after his visit there a century and a half ago, that fascination invested them with more than just the status of benighted savagery that had previously prevailed. To be

Received June 23, accepted July 3, 1989. 
sure, much of that judgment continued unabated, but to it was added an implication of the "primitive" in an evolutionary sense. Whether overt or unspoken, there has been a general assumption that Australian Aborigines represent the survival of an earlier stage in human evolution. Whatever their age or sex, they have been repeatedly designated by the collective term "primitive man," a kind of Pleistocene vestige that has been regarded as a veritable living fossil.

This sort of appraisal has the same kind of typological essentialism to it that underlies the urge to identify cladistic status or "race" (Brace, 1988). But if cladistic assessment and racial designation are equally subjective enterprises, what can we do to make sense in our consideration of those aforementioned Australian Aborigines or any other human group during the course of an investigation of the spectrum of variation in $H$. sapiens?

There are in fact two general approaches that can be productive in very different ways to help us understand the nature and relationships of any given population. One such approach is to assess the adaptive state of separate traits one by one in the perspective of the intensity and temporal duration of the individual selective force that applies to each. The other is to assess the similarities to and differences from other populations, both near and far, by using traits and configurations that have little adaptive significance in and of themselves. No one study of limited scope can hope to do complete justice to both approaches. At best, one can aspire to provide an illustration of how and why each one can work. We attempt to do this in the sections that follow.

\section{THEORETICAL BACKGROUND \\ The demise of racial classification}

A generation and more ago, physical anthropology considered racial classification to be one of its principal tasks, and the preferred technique used in the pursuit of this goal was the comparative use of nonadaptive traits (Hooton, 1926, 1931). Subsequently the enthusiasm for the use of nonadaptive dimensions of morphology waned (Hooton, 1946), and, with the Fisherian insistence that selection was the sole mechanism controlling evolution, it became the accepted view that all aspects of morphology were controlled by selection and nothing could be regarded as non-adaptive (Dobzhansky,
1944; Lack, 1961; Gould and Lewontin, 1979). The rise of the synthetic theory of evolution redirected scholarly enthusiasm towards the study of characteristics with measurable adaptive value, and the maturation of the science of genetics focused attention on traits with simple and discoverable modes of inheritance, whatever their adaptive significance. Partially as a result of these developments, the relevance of skeletal studies in general came under an increasingly vocal attack (Boyd, 1950) that has continued up until the present (Renfrew, 1987). Initially, however, this simply served to shift the basis on which classification was established from the morphological phenotypic level to the serological genotypic level.

Classification involved the identification and naming of a presumably fixed number of "races," whose individual members each contained traits considered to be uniquely characteristic of the "race" in question. Still earlier, during the nineteenth century, there was a general consensus in physical anthropology that the various "races" had been fixed entities for an immeasurably long period of time, possibly reflecting original creations-separate and unequal (Brace, 1982). With the superficial addition of an evolutionary dimension to the expectations of physical anthropologists as the twentieth century proceeded, the idea grew that each "race" had a different evolutionary trajectory, and that each had evolved to a greater or lesser extent in comparison to each other (Coon, 1962). The assumption of differences in timing and degree of that evolution allowed the preservation of an assumed hierarchy no different in effect from the idea that differences in worth had existed ad initio, and it underlies the invidious comparisons that continue to be offered (Rushton, 1985, 1987, 1988).

Finally, the concept of race itself was shown to be devoid of biological justification (Livingstone, 1962; Brace, 1964a,b). Consequently the whole enterprise of racial classification, once at the core of professional physical anthropology, was deprived of its scientific credibility and basically ceased to exist. The social scientist, cognizant of the inequities and injustices perpetrated in the name of "race," could well cry "good riddance."

But human beings are not identical clones, and their differences have regional and temporal aspects to them that should certainly 
be the legitimate concern for biological anthropologists. Some investigators have actually chosen to deal with one or another trait whose manifestation can be associated with differences in the intensity or duration of specific selective forces (Livingstone, 1958, in press; Brace, 1967, 1977, 1979, 1980; Brace et al., 1987, in press c). Others have concentrated on particular single gene phenomena and investigated the evidence for genetic drift and the founder effect in island populations or other remote genetic isolates Glass et al., 1952; Friedlaender and Steinberg, 1970; Neel, 1970; Morton and Lalouel, 1973). Somewhat more ambitious attempts have been made to use multiple loci to assess within and between group similarities and differences of a more extensive regional nature (Smouse et al., 1982).

Until recently, however, the whole matter of population relationships that used to be subsumed under the rubric of "racial classification" has been left relatively untouched. Underlying this de facto abdication of concern is the sometimes privately expressed fear that any attempt to deal with this matter would simply allow observers to establish a hierarchical ranking of human groups with all of the invidious implications once associated with the racial classifications of the past. We propose to show, however, that the matter of relationships can be treated in perfectly objective fashion without the implications inherent in the terms "race," "type" or whatever, and in such a way that no group can be judged either more or less fit, "higher" or "lower," or better or worse than any other. In this endeavor, our efforts represent an extension of the pioneering work initiated at Mainz by Schwidetzky and those who have continued in that tradition (Schwidetzky and Rösing, 1984; Sokal and Uytterschaut, 1987; Sokal et al., 1987, 1988; Harding and Sokal, 1988).

\section{Lessons from molecular biology}

The accumulating record of ongoing and successful research in molecular biology may have shown us a way out of the dilemma inherent in "classification." Certainly it is worth the effort to look at the matter and see if the underlying logic can be extended to deal with morphology as well as with molecules.

The study of mitochondrial DNA has produced promising and provocative results (Wallace et al., 1985; Cann et al., 1987;
Smouse and Li, 1987; Cann, 1988; Excoffier and Langaney, 1989), but there are some stochastic problems and other pitfalls that keep it from being our best general model (Weiss, 1987; Spuhler, 1988, 1989). The appraisal of nuclear DNA on the other hand, and despite some of its own attendant problems, can function as our basic example. Ideally this would be best approached by codon sequencing. In practice, however, this is a tedious and nearly interminable process. Doubts have also been expressed by some concerning the effectiveness of what has been demonstrated by crude "brute force" DNA-DNA comparisons because of some of the methodological problems involved (Marks, 1988; Marks et al., 1988). In addition, it was thought that the different adaptive significances of individual base pairs have not been taken into account, and further doubts were expressed because of the indeterminant nature of just what is being measured when a stated level of concordance is reached (McKenna, 1987). This has been anticipated by the molecular geneticists who note that perhaps $90 \%$ of the genome does not code for anything and hence is adaptively neutral, designated by the term "junk DNA" (Ohno, 1970; Nei, 1983, 1987). Given this, the differences observed should be mainly related to time elapsed since divergence (Sibley and Ahlquist, 1983, 1987a). In any case, the arguments over why it should or should not work have been effectively muted by the obvious fact that it does. Although arguments continue about various aspects of fine tuning, the overall pictures of phylogenetic relationship it has produced for birds, primates, and other living creatures (Sibley and Ahlquist, 1986, 1987a,b; O'Brien, 1987) have convinced many observers that DNADNA hybridization comparisons work. Furthermore, they work precisely because so much of the genome has no adaptive significance. The logic of why this should be so was articulated by Charles Darwin himself when he observed that "as a general rule, ... the less any part of the organisation is concerned with special habits, the more important it becomes for classification" (Darwin, 1859: 414). And he continued with the converse, noting that "adaptive characters, although of the utmost importance to the welfare of the being, are almost valueless to the systematist" (1859:427).

By "classification" he did not mean any kind of ranking in the eyes of a putative "creator" or position in a hypothetical chain 
of being. Rather he was simply referring to degree of relationship between one individual or group with another where that degree of relationship reflects evolutionary history-the time elapsed since descent from a common ancestor. Darwin, of course, was speaking of aspects of the phenotype, and, although it is now obvious that his logic also works at the genotypic level, it would be interesting to see if we could put it to the test at the phenotypic level at which he conceived of it in the first place.

\section{Nonadaptive features and population relationships}

There remains the problem of whether there is such a thing as a "non-adaptive trait" and, if indeed there is, how we could recognize any number or even one of such. We can argue that old-fashioned physical anthropology managed to discover them in almost ludicrous abundance. For example, one need only scan the papers and monographs of two or three generations ago to encounter countless enumerations of traits that have yet to be shown to have any vestige of adaptive significance. What possible difference in selective value might there be in having a cranial contour that is ovoid as opposed to pentagonal-or any other of the myriad of named shapes? Why on Earth would it be better to have high rounded orbits under some circumstances and low rectangular ones under others? And when one turns to the assessment of the "soft parts," the same kinds of questions remain. What can we learn about human survival capabilities from an assessment of differences in lip seam development? And of what value were those extensive investigations of female breast form other than as measures of the ostensibly legitimized lechery of a previous generation of male investigators (Ploss, 1872; Ploss and Bartels, 1899; Ploss et al., 1938; Mercier, 1873; Stratz, 1898, 1901; Hoerschelmann, 1904; Lipiez, 1907; Witkowski, 1907; Bloch, 1909; Rothe, 1912; Hooton, 1918; Holl, 1920a,b; Martin, 1928a)? Those who insist that selection must be the main controlling factor, even if we cannot see how it works, have been compared by Gould and Lewontin to the figure of Dr. Pangloss in "Candide," who maintained, despite the mounting record of personal disasters, that all was for the best in this the best of all possible worlds (Gould and Lewontin, 1979). Both the "hyperselectionists" and the pious eighteenth-century objects of Voltaire's satire represent the conviction that, although the workings of nature on the one hand and God on the other may be beyond the grasp of human reason, the nature of the world assumed by their various manifestations of a priori faith continues to be fully valid even if not discernible or testable (Brace et al., in press c).

\section{The construction of nonracial clusters}

Although this will continue to remain a controversial point, we suggest that there is a pragmatic approach that may well produce a de facto solution. With the demonstration by human geneticists that ". . . on a per character basis, anthropometric traits discriminate better than genetic traits" (Spielman and Smouse, 1976:328), and the pragmatic support of the theoreticians of numerical taxonomy (Sneath and Sokal, 1973), we have been encouraged to use morphometrics in an attempt to deal with human population relationships. Furthermore, referring back to the example of the DNA-DNA hybridizers, if we simply include a plethora of dimensions, we might be able to produce the same kind of "brute force" results. We have inadvertently done something very much like this, and we take this occasion to display the preliminary results. This was inadvertent because we actually had tried to use a set of measurements designed to discriminate between populations in features that presumably differed because of differences in selective force intensity (Brace et al., 1989, in press a). Although we did succeed in getting a picture of population relationships that served our purposes, we discovered that the picture became even sharper when we simply added more measurements without any regard for the possible adaptive significance of the underlying dimension. In fact, we have merely rediscovered what eighteenth century naturalists such as Buffon and Blumenbach had realized, namely, that the best results will follow from the use of the "greatest possible number of characters" (Mayr, 1965:73). In the same somewhat inadvertent vein, the satisfactory nature of our results demonstrates in empirical fashion the aptness of Sneath and Sokal's observation that, although there may be redundancy in the use of correlated variables, it is more than "coun- 
terbalanced" by the additional information obtained (Sneath and Sokal, 1973:106).

Actually, what DNA-DNA hybridization studies and our own morphometric efforts have produced are branching diagrams depicting phenetic relationships using large quantities of available but unweighted characters. To use Cain and Harrison's term, these are phenograms (Cain and Harrison, 1960:3; Mayr, 1965) in the classic sense of numerical taxonomy (Sokal and Sneath, 1963; Sokal, 1965; Sokal et al., 1965; Sneath and Sokal, 1973), or "numerical phenetics" as Mayr prefers (Mayr, 1965, 1982:222). Although there is a perception that this approach "has become a bit unfashionable lately," our efforts might just qualify as a representation of the "comeback" expected by the author of that comment (Dawkins, 1986:281).

One choleric critic has characterized the use of DNA-DNA hybridization to generate such diagrams for the purpose of indicating population relationships as "a dubious mixture of phenetic and cladistic methodology" (McKenna, 1987:57), but at least it avoids the manifest subjectivity of standard cladistic procedure (and see Schwartz, 1984, for a particularly risible example of the latter). In any case, we present a series of dendrograms for modern and recent prehistoric human groups that we suggest have several advantages. First, they agree well with linguistic, ethnographic, and historical accounts, and they can be checked against the available archaeological information. Second, this approach provides a means of dealing with human biological variation that can be used to group and compare human populations without the attendant danger of creating anything comparable to a racial typology with the possible attribution of relative worth that was inevitably associated with this activity in the past. In essence, it is a nonracial and noninvidious means of comparing the general biological similarities and differences of human populations. And, finally, it allows us to deal with both past and living populations, something that is beyond the reach of those who confine their analysis to the study of the genome itself.

\section{DATA SELECTION AND TREATMENT Craniofacial variables}

In the course of investigating the evidence for dental reduction in the recent human past, we had to deal with the question of whether the reduction recorded in a given area actually took place in situ or whether it was the result of immigration and dilution or replacement by a population from some other area. Since we were attempting to test the continuity or lack of continuity between prehistoric and modern groups, we were restricted to the use of variables that could be assessed with equal ease on both. Of necessity, this meant that we had to seek our data on skeletal material. And, since our initial focus was on odontometrics, it was only logical that our test should focus on the use of the craniofacial material that provided us with our dental samples.

To avoid the possible taint of subjectivity associated with the assessment of character state or other kinds of nonquantitative analysis, we chose to restrict our efforts to the collection of craniofacial metric information. We started with a selection of the measurements used by Howells in his study "Cranial Variation in Man" (Howells, 1973) and added a few variables that we hoped would improve our ability to test similarities and differences. In successive years, we added further measurements, until we now have a full two dozen. The complete roster appears in Table 1.

Since we added items to our list after we had started, this means that the groups mea-

TABLE 1. Craniofacial measurements used in this study

\author{
Nasal height (Martin No. 55) \\ Nasal bone height (Martin No. 56[2]) \\ Piriform aperture height (Martin No. 55[1]) \\ Nasion prosthion length (Martin No. 48) \\ Nasion basion (Martin No. 5) \\ Basion prosthion (Martin No. 40) \\ Superior nasal bone width (Martin No. 57[2]) \\ Simotic width \\ Inferior nasal bone width (Martin No. 57[3]) \\ Nasal breadth (Martin No. 54) \\ Simotic subtense ${ }^{2}$ \\ Inferior simotic subtense \\ FOW subtense at nasion \\ MOW subtense at rhinion ${ }^{3}$ \\ Bizygomatic breadth (Martin No. 54) \\ Glabella opisthocranion (Martin No. I) \\ Maximum cranial breadth (Martin No. 8) \\ Basion bregma (Martin No. 17) \\ Basion rhinion \\ Width at 13 (fmt-fmt) \\ Width at 14 \\ IOW subtense at nasion 3 \\ Width at 22 (fmo-fmo) \\ Minimum nasal tip elevation
}

'Martin numbers are from Martin (1928b).

Howells (1973)

Woo and Morant (1934). 
sured at the beginning of our project were represented by fewer variables than the ones most recently studied. In some cases, it was possible to return to the collections and add the variables not measured on the first visit. It was in the course of this that we discovered the curious fact that our ability to cluster and distinguish was more dependent on the sheer quantity of variables used than it was on the care with which we selected them, a finding that provides empirical support for the intuitively based position taken by the promoters of numerical taxonomy (Sneath and Sokal, 1973). We also discovered that, beyond the first twenty or thirty individuals per group, our reliability in constructing our assessments was not changed even when we increased our numbers to one or two hundred cases for each of the variables.

\section{Data treatment: $C$ score computation and use}

To start with, we collected data from a series of samples using the measurements listed in Table 1. In Table 2, we show the names of the groups we tested along with the number of individuals used in each and the locations of the collections in which they are stored.

We thought that comparisons of the kind we wished to make would be accomplished best by concentrating on relative proportion or "shape" alone and reducing the effect of sheer size on the results of our analysis. To accomplish this, we converted our data to $\mathrm{C}$ scores according to the procedure described by Howells (1986). This adjusts for size by comparing each measurement on an individual to the overall size of all measurements of

TABLE 2. Average and range of $N$ and location of collections for the samples used in phenograms (footnotes give locations at which skeletal collections are housed)

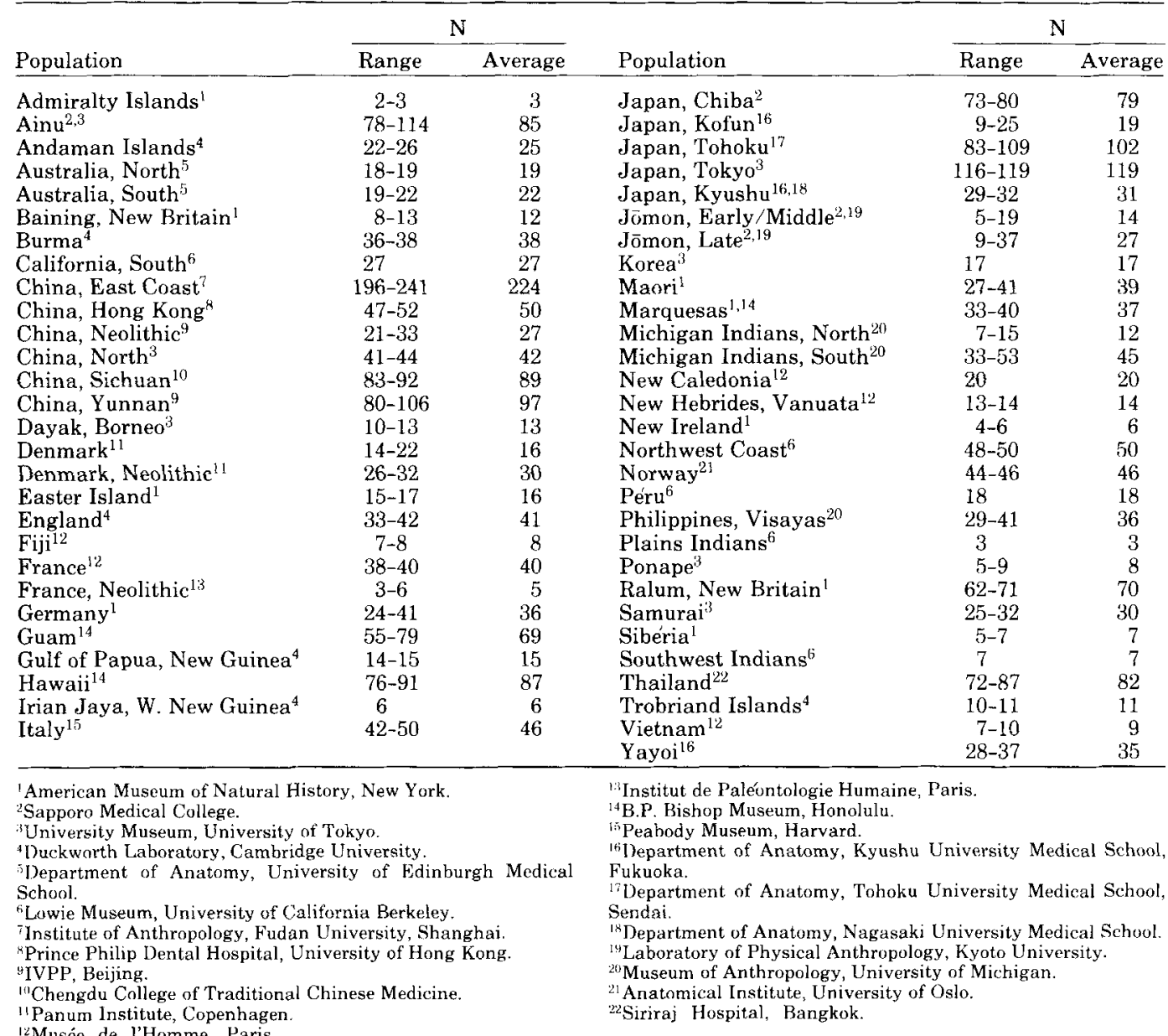


the cranium. $\mathrm{C}$ scores are similar to ratios in that they both are measures of relative size. The advantage of a $\mathrm{C}$ score over a simple ratio is that the $\mathrm{C}$ score reflects the relative size of a given feature in comparison to the average relative size of all the other traits used, whereas a ratio can reflect only relative size in comparison with a single referent. C scores are calculated as follows. First, individual unweighted measurements are converted into sex-specific standardized scores ( $\mathrm{Z}$ scores), where each $\mathrm{Z}$ score represents the number of standard deviation units by which the value in question departs from the grand mean of that variable for all the samples used in a given analysis.

This can be represented as:

$$
\mathrm{Z}_{\mathrm{ij}}=\frac{\left(\mathrm{X}_{\mathrm{ij}}-\overline{\mathrm{X}}_{\mathrm{i}}\right)}{\sigma_{\mathrm{i}}},
$$

where $\mathrm{i}=$ number of the measurement (e.g., $1 . .24), \mathrm{j}=$ number of the individual, $\mathrm{X}_{\mathrm{ij}}=$ value of measurement "i" for individual " $\mathrm{j}, \overline{\mathrm{X}}_{\mathrm{i}}=$ overall sex specific average value for measurement " $i$," and $\sigma_{i}=$ overall sex specific standard deviation for measurement "i."

From $\mathrm{Z}$ scores, $\mathrm{C}$ scores are calculated as the difference between the $Z$ score of a single measurement for a given individual and the mean $Z$ score of that individual for all the measurements used in the analysis.

The mean $\mathrm{Z}$ score of an individual is calculated as follows:

$$
\bar{Z}_{j}=\frac{\sum_{i=1}^{N} Z_{i j}}{N},
$$

where $\bar{Z}_{\mathrm{j}}=$ the average $\mathrm{Z}$ score for all the variables for individual " $\mathrm{j}$ " and $\mathrm{N}=$ the number of variables used (e.g., 24 if all are represented). Given this, the C score for variable $i$ for individual $\mathrm{j}$ is:

$$
\mathrm{C}_{\mathrm{ij}}=\mathrm{Z}_{\mathrm{ij}}-\overline{\mathrm{Z}}_{\mathrm{j}}
$$

As Howells described this procedure, it has the requirement that all variables be present on each of the specimens used. This frequently presents a problem in the analysis of prehistoric populations since the number of complete specimens is often small to nonexistent.

Others have occasionally used various multiple regression procedures for interpo- lating missing variables, but we decided against this. In our analysis we use up to 24 measurements, but, instead of calculating an average $Z$ score only for individuals with all 24 variables, we calculated average $Z$ scores if 15 or more variables were present on any one individual. These average Z scores were then used to compute the $C$ scores for each of the variables present in each individual as in equation 3 . A mean $\mathrm{C}$ score was then calculated for each variable by sex and by population, and these sexspecific $\mathrm{C}$ scores were used to generate the male-female midsex mean $\mathrm{C}$ scores $\left(\overline{\mathrm{C}}_{i J}\right)$ that we then used as the basis of our groupby-group comparisons.

More formally,

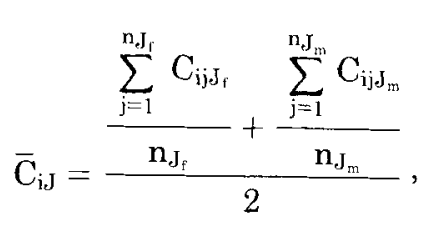

where $\mathrm{i}=$ number of the measurement (e.g., $1 \ldots 24), j=$ number of the individual, $\mathrm{J}=\mathrm{a}$ population, e.g., Japan, $J_{f}=$ females only from population $\mathrm{J}, \mathrm{J}_{\mathrm{m}}=$ males only from population $J$, and, therefore, $\mathrm{C}_{\mathrm{ij} \mathrm{J}_{\mathrm{f}}}$ represents the $\mathrm{C}$ score for the $\mathrm{i}$ th measurement, for the $\mathrm{j} t h$ individual among the females of the Jth population.

Once we had generated a mean $\mathrm{C}$ score for each variable by population $\left(\bar{C}_{\mathrm{ij}}\right)$, we analyzed the data using a cluster algorithm available in the Michigan Interactive Data Analysis System (Fox and Guire, 1976). This algorithm produces branching diagrams in which populations are arranged according to their Euclidean distance from one another. Groups are displayed as twigs on a tree where the distance between each branching point is roughly proportional to Euclidean distance (Sokal and Sneath, 1963; Sokal and Camin, 1965; Sokal, 1966; Sokal and Rohlf, 1969; Sneath and Sokal, 1973; Fox and Guire, 1976).

We did a series of trial runs to test whether our use of individuals with different numbers of variables present for the purpose of generating mean $\mathrm{C}$ scores had any effect on the nature of the clusters that were produced. In the case of the treatment of relatively large groups, i.e., those with Ns of over 25 for each sex, the major clusters were exactly the same. In the cases with smaller $\mathrm{Ns}$, our procedure tended to produce more 
satisfying results than was the case when only individuals with complete data were included. For example, it eliminated the curiosity of seeing an Amerindian group or two appear in the European or the AustraloMelanesian clusters. As will be seen in what follows, our results are sufficiently consistent for us to be confident in the validity of our procedure.

\section{PRACTICAL APPLICATION Japan}

Our first attempt to use this technique for a population analysis problem was focused on Japan. We used C scores as the input to generate a Euclidean distance dendrogram to see whether the modern Japanese clustered with their Jōmon predecessors or with other previous and modern Asian groups. First we restricted our attention to the data from the Japanese archipelago itself. Figure 1 shows that the modern Japanese fall into the same cluster as the Yayoi rice agriculturalists who entered Japan in $300 \mathrm{BC}$ and also with the Kofun tomb builders, who were the immediate predecessors of the emergence of the Yamato State in the sixth century. The Jomon, associated with the development of pottery in Japan more than 10,000 years ago, fall into the cluster with the modern Ainu. This confirms the conclusions previously reached by the appraisals of craniofacial form (Koganei, 1903, 1927; Brace and Nagai, 1982) and the nonmetric characteristics of the dentition (Turner, 1976, 1986).

The Jomon-Ainu association of a putative group of Samurai, killed during the overthrow of the Kamakura Shogunate in 1333, is an interesting demonstration of how this analytical approach can cast light on partic-

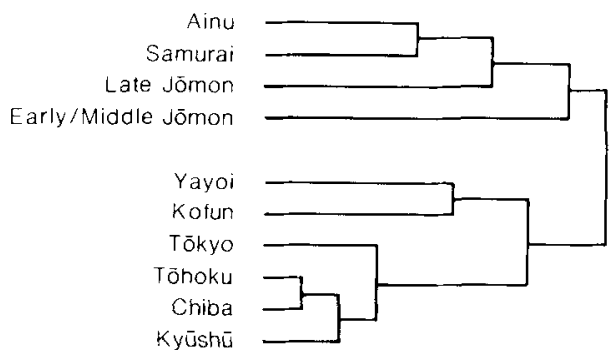

Fig. 1. Euclidean distance dendrogram comparing the prehistoric and modern populations of Japan. All dendrograms are based on C scores; see text for explanation. ular aspects of population history and has been dealt with elsewhere in greater detail (Brace et al., 1989). It is a curious irony that the facial features associated with high social status in Japan and glorified in Japanese art evidently represent the genetic contribution that the despised Ainu have made to the traditional Samurai class.

Japan, however, for all its long and independent history, shares many cultural elements with the neighboring Asian mainland, and it has been a matter of long-term observation that the Japanese characteristically display facial features that ally them with their mainland Asian neighbors. At the same time, during work on the prehistoric Jomon skeletal collections, we were struck by the similarities between the configuration of their features and those visible in some of the crania from Oceania. The obvious course of action was to test this by including Japanese, Oceanic, and mainland Asian crania in a single analysis. The results of this can be seen in Figure 2.

As can be seen, the Japanese along with the prehistoric Yayoi rice agriculturalists are included in the same cluster with the mainland Asian groups tested. The Mainland Asian cluster further is broadly separated into a northern and a southern component. The northern component includes the northern Chinese Neolithic, modern coastal Chinese, Koreans, and Japanese. The Ainu and the prehistoric Jomon, however, fall into a cluster with Micronesians and Polynesians. This has been called the Jomon-Pacific cluster (Brace et al., 1989, in press a, b).

\section{Oceania and Australia}

The process by which the settlement of Oceania was accomplished has been an active focus of interest by archaeologists and culture historians for some time (Green, 1973, 1986; Bellwood, 1975, 1979; Jennings, 1979), and some very contradictory models have been proposed. These range from the vision of a figurative Austronesian "fast train" from the Asian mainland, or the postulation of a Lapita "homeland" in the Bismarcks of northwestern Melanesia (Allen, 1984; Kirch et al., 1989), to the suggestion that Polynesians emerged by transformation out of eastern Melanesians somewhere in the neighborhood of New Caledonia (Terrell, 1986). This would appear to be an ideal situation in which to test the effectiveness of 


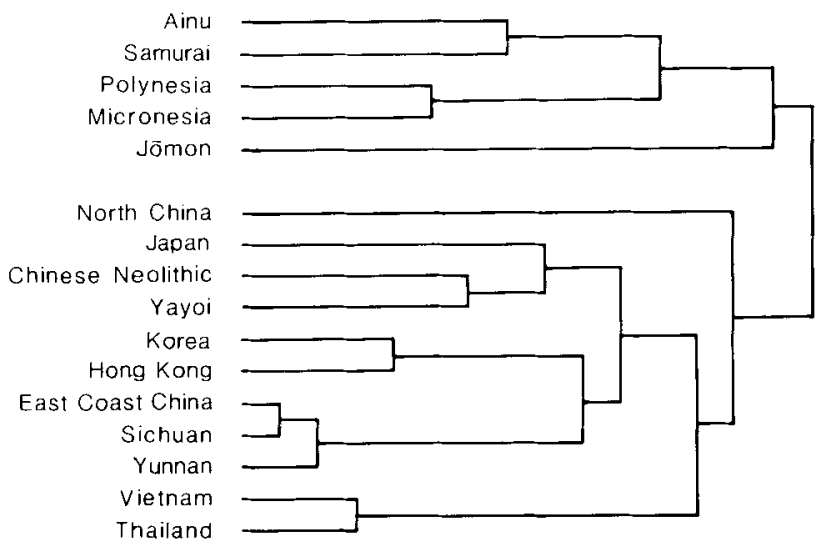

Fig. 2. Euclidean distance dendrogram comparing a series of populations from the Asian mainland, Japan, and the islands of Micronesia and Polynesia.

the approach we are advocating. We have presented a preliminary treatment of this matter elsewhere (Brace et al., in press a), but we have subsequently added some further populations to fill in areas previously unrepresented.

In dealing with this matter, we have had to organize things to consider the oft-reiterated observation that the Melanesian inhabitants of Oceania are closely related to Tasmanians, Australians, and the inhabitants of New Guinea (Sarasin, 1924; Wagner, 1937; Howells, 1973). Figure 3 shows what happens when we compare the various peoples of the Pacific with those who produced the Mainland Asian cluster. The Jomon-Pacific cluster retains its identity, and all the groups found in Melanesia, New Guinea, and Australia form a separate coherent cluster, which we have termed the Australo-Melanesian cluster. It is a matter of added interest that the available specimens representing the Andaman Islands also fall into this cluster, although the tie is not close. Still, the Australo-Melanesian group with which they form their closest association is the westernmost for which we have data from the island of New Guinea itself. This, with other subjective hints previously noted, gives some support to the expectation that groups that would have been recognized as members of this cluster once may have been distributed west of New Guinea throughout what is now Indonesia.

With Easter Island, Hawaii, and the Maori of New Zealand in the far Pacific fitting comfortably in the same cluster with the
Ainu and the prehistoric Jōmon of Japan, there is virtually no likelihood that any members of what has been termed the Jómon-Pacific cluster could have emerged by transformation from anything in either western or eastern Melanesia. And with the representatives of the latter from New Britain and New Ireland to New Caledonia and the New Hebrides solidly associated in the same cluster with both northern and southern Australian aborigines as well as groups from the Gulf of Papua in New Guinea, there is every reason to believe that the members of the Australo-Melanesian cluster have a common inheritance that goes well back into the Pleistocene. Archaeological evidence for human occupation of the Swan River region of southwestern Australia (Pearce and Barbetti, 1981) and the Huon Peninsula of northern New Guinea goes back more than 40,000 years (Groube et al., 1986) and is supported by prepottery sites of more or less comparable antiquity in the Bismarck Archipelago of western Melanesia.

Altogether, this sustains the suspicion previously offered, largely on the basis of tooth size alone, that an area extending from the Andaman Islands in the west through Borneo and the Philippines to the large islands of Melanesia and including New Guinea and Australia was populated by people of common ancestry and similar appearance during the latter part of the Pleistocene (Brace and Hinton, 1981). Figure 4 shows the putative extent of this related series of populations and suggests the routes by which their spread into the regions be- 
Andaman islands

West New Guinea

Trobriand Islands

Gulf of Papua

New Hebrides

New Britain

North Australia

South Australia

Fiji

New Caledonia

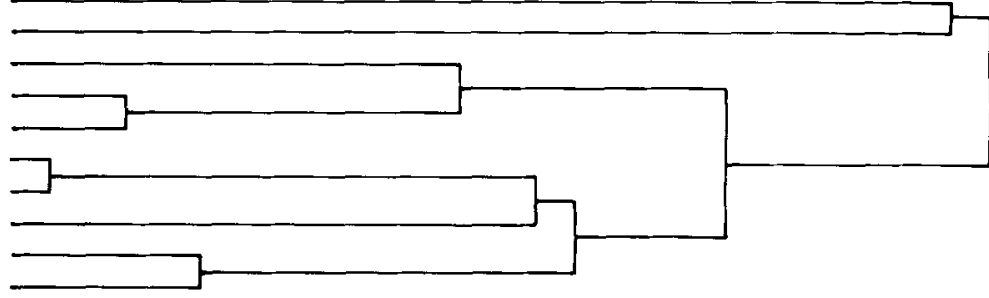

Jōmon Japan

Ainu

Samurai

Hawaii

Guam

Maori

Marquesas

Ponape

Shanghai China

Korea

Neolithic China

Yayoi

Tokyo Japan

Siberia

Vietnam

Thai

Burma

Borneo

Philippine

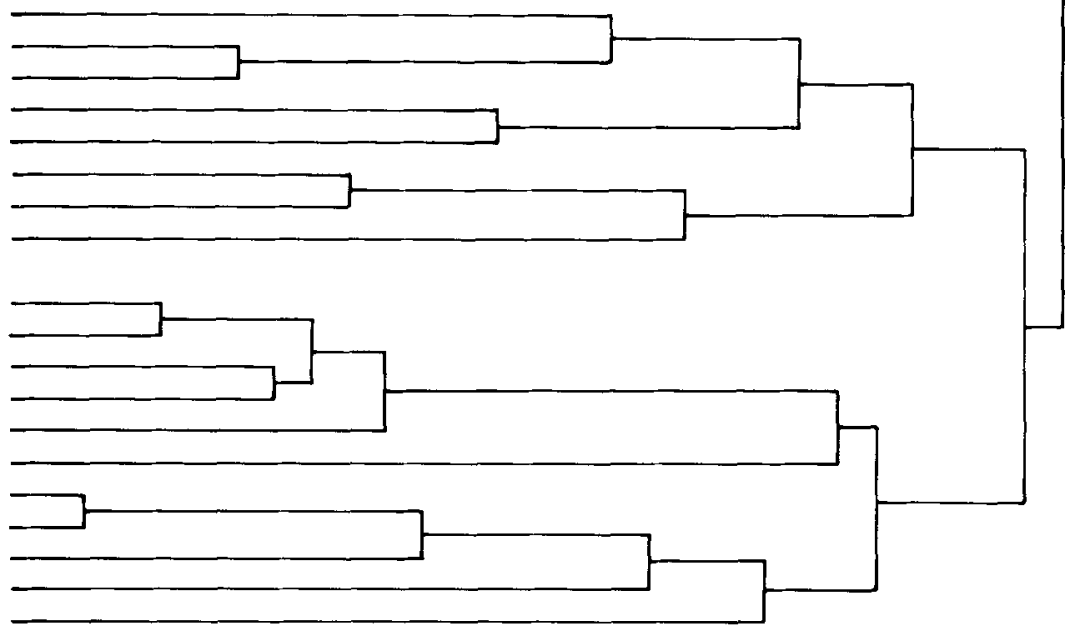

Fig. 3. Euclidean distance dendrogram comparing samples from the Asian Mainland, Micronesia, Polynesia, Melanesia, and Australia.

yond Wallace's line was presumably accomplished.

Then, to get a population of a very different appearance out into the small islands of the far Pacific between 4,000 and 2,000 years ago, some version of Bellwood's express train model has to be invoked. There have been archaeological attempts to identify a southeast Asian source (Solheim, 1964, 1972, 1976; Spoehr, 1973), and Turner has used data from dental morphology to suggest that what had been Sundaland at the time of lowered sea levels in the Late Pleistocene was the most likely area (Turner, 1986, 1987).

However, the oldest human skeletal material solidly aligned with the members of the Jomon-Pacific cluster are the Early Jömon specimens themselves from approximately 6,000 years ago in Japan. On purely archaeological evidence, the Jomon goes back much farther than that (Ikawa-Smith, 1980; Pearson, 1986), and, if the 18,000-year-old Minatogawa skull from Okinawa can be used as further evidence (Suzuki, 1981; Suzuki and Hanihara, 1982; Turner, 1983, 1989, in press), then there is at least a tentative reason to offer Japan and the Ryukyu Archipelago as the source from which subsequent expansion produced the distribution of the related peoples who form the Jōmon-Pacific cluster. This possibility is illustrated by the routes of movement depicted in Figure 5.

\section{Other parts of the world}

The success we have had using this cluster-producing method to suggest population relationships in Asia and the Pacific has led us to extend our efforts to include representatives from other major regions of the world. Figure 6 shows what happens when a series of European and Amerindian groups is added to what has already been examined. It is no surprise to discover that the two additional series make distinct, separate clusters. In the Amerindian cluster, one of the constituent groups, the Southwest, appears to be less closely related to the others and, in 


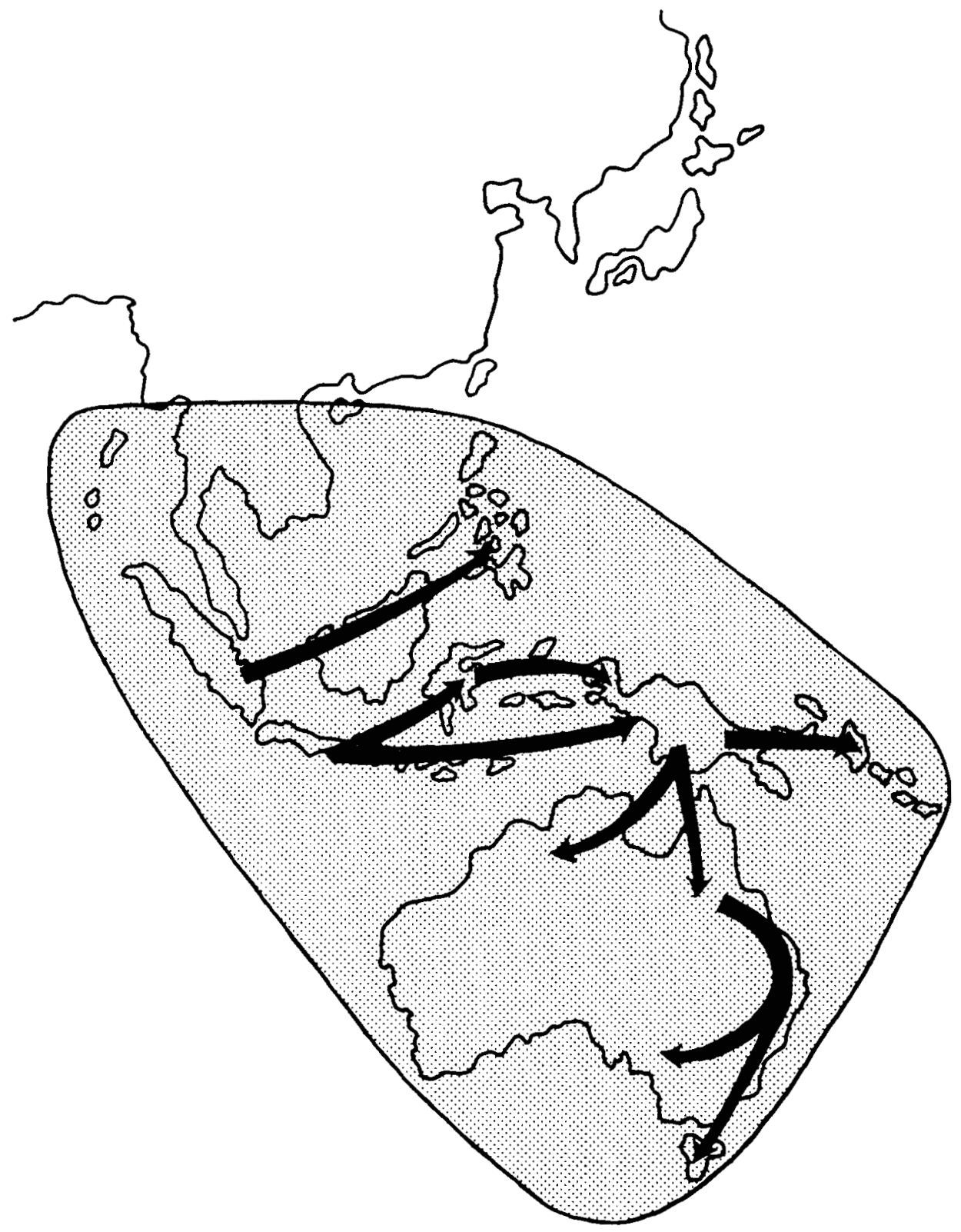

Fig. 4. The stippling represents the suggested area of occupation late in the Pleistocene of a large-toothed series of people of relatively similar appearance. The arrows show the presumed routes of initial Late Pleistocene movement into the Philippines and beyond Wallace's Line into the large islands of Melanesia and Australia. (Adapted from Brace and Hinton, 1981, with permission of the publisher.)

a sense, almost intermediate between the Amerindian cluster and the European cluster. As it happens, we were dubious about this even before we ran the cluster- producing program, but we included it anyway since we had nothing else to represent that end of the Australia-to-Zuni spectrum. Our suspicions arose from the possibility 


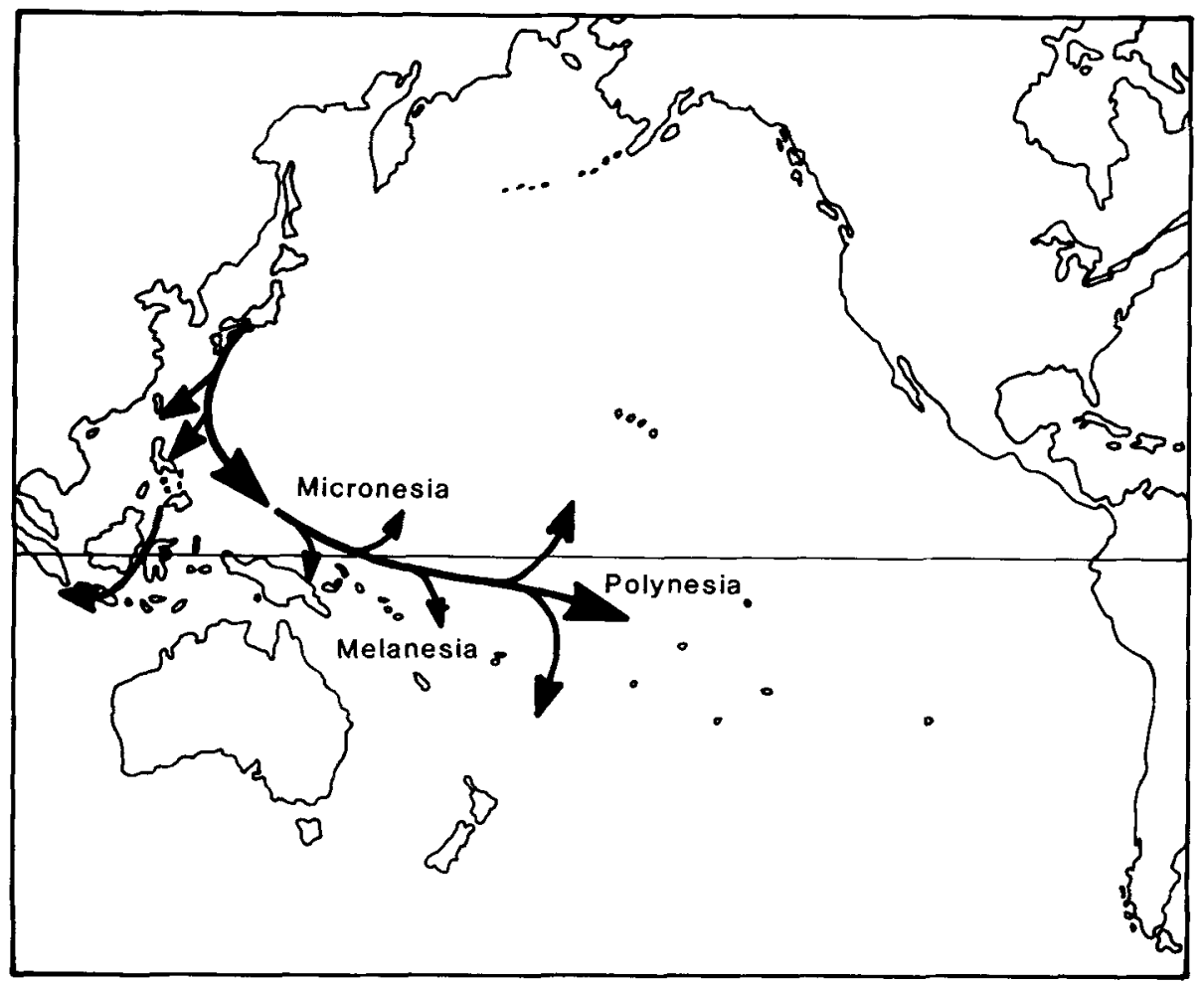

Fig. 5. The suggested route of spread of the Jōmon-Pacific movement from its hypothetical area of origin out into the small islands of the Pacific. (Adapted from Brace et al., 1989, with permission of the publisher.)

that the form of the skulls from the American Southwest had been altered by artificial deformation. A great deal of the available material was rejected out of hand because the deformation was obvious. Although we tried to select specimens that did not appear to have been deformed, nonetheless we still had the uneasy feeling that there were virtually no completely undeformed individuals. Obviously we need to add many more representatives of each region treated before we can be more than tentative about the nature and extent of each such grouping.

What does come as something of a surprise, however, is the relatively complete separation of the Amerindian cluster from the Mainland Asian and the Jōmon-Pacific clusters. Evidently the 12,000 or 13,000 year time span since the presumed initial movement into the New World (Irving, 1985; Fagan, 1987; Haynes, 1988) was sufficient for the production of the distinctions observed. The computer program that produces dendrograms from our $\mathrm{C}$ scores also generates Mahalanobis $\mathrm{D}^{2}$ figures, which express a numerical form of the Euclidean distance between any given group and each of the others (Sokal, 1965). It is our hope that we may eventually be able to use such figures as measures of separation time when we have been able to collect enough information on lineage change through time and on reliably dated separations of known groups. At the moment, however, this is a long way from being achieved, which is why we have not included a table of the alreadyponderous matrix of $\mathrm{D}^{2}$ figures.

\section{TOOTH SIZE AS A MODEL FOR ADAPTIVE TRAIT CONSIDERATIONS}

Because of the quantity of information available and the various other reasons mentioned in extensive previous discussions (Brace, 1967, 1978, 1979, 1980; Brace and Mahler, 1971; Brace and Hinton, 1981; Brace and Nagai, 1982; Brace et al., 1984, 1987; Brace and Vitzthum, 1984), we have concentrated our consideration of dimen- 


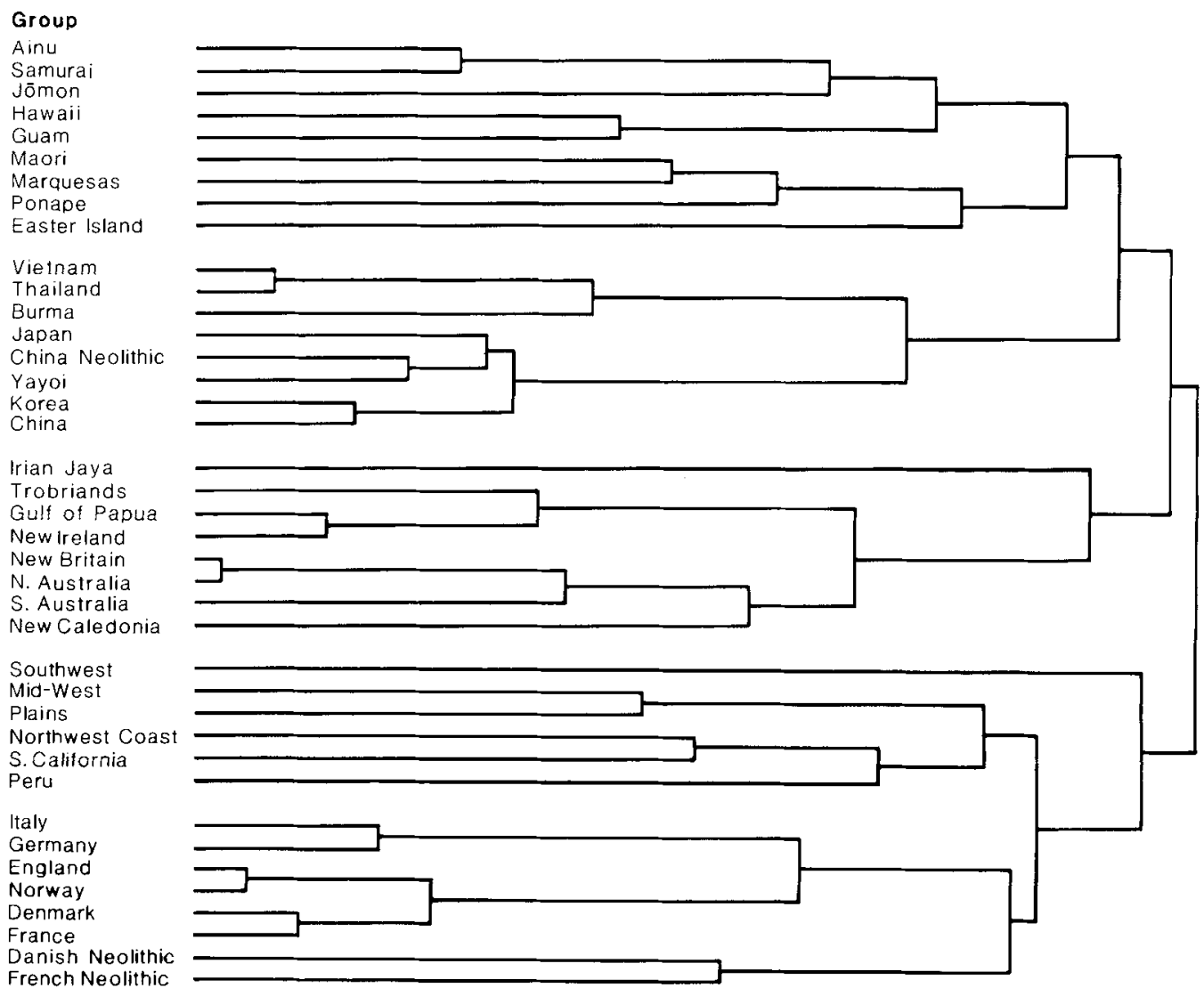

Fig. 6. Euclidean distance dendrogram showing the nature of the clusters when a series of representative Amerindian and European groups are added. The clusters shown in Figure 3 retain their identity, and Europe and the whole of the aboriginal western hemisphere appear as comparably identifiable clusters.

sions under obvious selective force control on the single trait of tooth size. We are aware, of course, that there are many parameters involved in tooth size, as can be seen when mesial-distal and buccal-lingual dimensions are treated separately or when anterior and postcanine or maxillary and mandibular teeth are compared (Brace et al., 1987). For purposes of simple demonstration, however, there is considerable heuristic value in treating tooth size as though it were a simple adaptive trait.

However, tooth size, like any other metric feature, shares a measure of common variance with body size as a whole. It would be desirable, then, to treat it in conjunction with some kind of body size index. Stature is notoriously poor as an indicator of body mass, and, furthermore, in many skeletal collections, there is no way to sort cranial and postcranial remains by individual, if indeed the postcranium is represented at all.

On the other hand, the teeth on which our measurements have been made are usually still in or at least associated with the skulls of their original owners. Since cranial measurements can give us a fair approximation of brain size (Pearson, 1926), and since brain size is allometrically related to body size within a given species (Lande, 1979; Martin, 1983; Martin and Harvey, 1985; Riska and Atchley, 1985), we have used the cranial and dental dimensions of the collections studied to investigate the relations between tooth size and body size. Our measure of tooth size, TS, is the cumulative sum of the cross-sectional areas (MD $\times \mathrm{BL}$ ) of all the maxillary and mandibular tooth classes (Brace, 1980). To calculate brain size, we treated the height, width, and length measurements of 
the brain case as though they were the major axes of an ellipsoid and used the standard formula to calculate its volume. Obviously we are aware that this will produce an overestimate of the actual size of the brain for several reasons (and note the attempt to correct for this made by Pearson in 1926), but it does give us a crude figure with which to work, and a case can be made that this will rise and fall in close approximation to the variation of true brain size itself.

Over a century ago, the English anatomist W.H. Flower used an even cruder index to determine whether the dentition in a given population was relatively large, medium, or small-"microdont, mesodont, and megadont" to use his terms (Flower, 1885). To do this, he measured the distance from the mesial surface of the maxillary first premolar to the distal surface of the third molar, a length that can be approximated by summing the mesial-distal dimensions of the five teeth involved. He then divided this figure by the nasion-basion length.

Flower's index, of course, is simply a proportion between two linear measures. Since our own appraisal of tooth size involves the calculation of areas and our approximation of brain size is a volumetric measure, we took the square root of the first and the cube root of the second in order to allow a direct comparison of Flower's index with our own. Despite the relatively crude approximations used by Flower, his measures show surprisingly high correlations with ours. For example, the correlation between our calculation of cranial volume and basion-nasion length is 0.813 , and that between his length measure of the maxillary postcanine teeth and our cross-sectional area of the entire dentition is 0.926 . Even though we believe that our own approach should yield a more reliable assessment, it is clear that Flower's index does indeed produce an easily calculated and very useful assessment of relative tooth size.

Figure 7 compares the assessment of a series of Asian and Oceanic populations by Flower's method and by our own, where the left-to-right position of the bars on the graph is determined by increasing magnitude of the TS/cranial volume index. As can be seen, the populations that are placed in the Jomon-Pacific cluster in our previous craniofacial analysis fall largely at the microdont end of the spectrum, the Australo-Melanesians all prove to be megadont, and the Mainland Asians are in between, just as
Flower himself observed over 100 years ago when he treated groups from those areas (Flower, 1885).

When we break down our comparisons to single dimensions and plot tooth size and brain size separately on the same graph, as in Figure 8 , it is obvious that they vary in quite unrelated fashion for the same set of populations plotted here in the same order as in Figure 7. The brain size-tooth size correlation across these groups in fact is negative, being -0.384 . This provides a graphic demonstration of the point that tooth size and body size have become decoupled during the recent course of human evolution (Brace et al., 1987). A full treatment of the changes in human tooth size that have followed the alterations in the relevant selective forces is being presented elsewhere (Brace et al., in press c).

\section{CONCLUSIONS}

A full understanding of the course of evolution requires the study of both phylogenetic relationships and the dynamics by which individual traits change through time, Darwin realized this 130 years ago with a clarity that has been appreciated by too few. Now that we have the advantages of both data and techniques that were unavailable in the past and can put his suggestions to the test, his genius seems ever more impressive.

But the effort to apply these to deal with problems in human phylogeny and evolution has suffered from their association with the invidious enterprise of racial classification in the physical anthropology of yesteryear. This is clearly expressed by Colin Renfrew in his recent book "Archaeology and Language," in which he says, "craniometry, the study and measurement of human skulls, has in recent years enjoyed about as much prestige in scientific circles as phrenology" (Renfrew, 1987:4). He continues, "there are at present few conclusions that can be relied upon" (p. 5) and concludes, "it would in my view be wrong to place much weight upon conclusions drawn from physical anthropology until the methodology is better developed" (p. 93).

We would argue, however, that the problem is less with the methodology than with the vision, or, rather, the lack of vision, of its users. As we have been able to show above, the use of nonadaptive traits to survey some representative human populations has enabled us to produce an assessment of the strength of their genetic relationships one to 


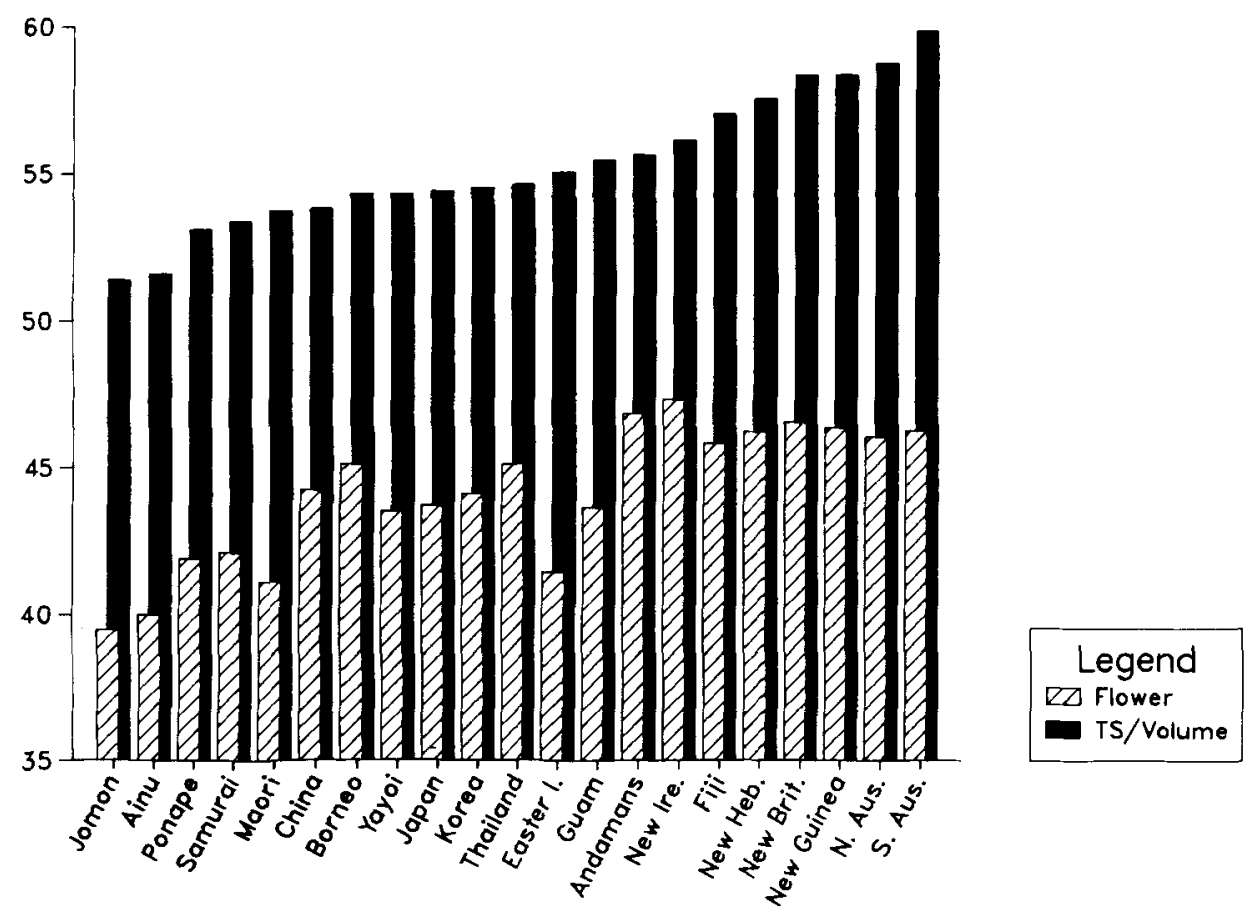

Fig. 7. The tooth size/cranial volume index for a series of Jōmon-Pacific, Mainland Asian, and Australo-Melanesian populations compared to Flower's index for the same groups. The increase in magnitude from left to right is keyed to the TS/BS index. Based on the data in Tables 3 and 4 .

another. Then, when we turned to the treatment of a trait under the changing influence of selection for different known periods of time in different areas of the world, we have been able to make interpretive sense out of a specific instance of evolutionary change. It is our hope that other investigators will follow this lead, dealing with still further human populations and other traits in the manner that we recommend. By these means, a coherent picture of human populations relationships and trait modifications-in sum, human evolution-has a very real chance of emerging in the near future.

\section{ACKNOWLEDGMENTS}

The research on which the project is based was accomplished in part with support provided by the Horace $\mathrm{H}$. Rackham School of Graduate Studies at the University of Michigan in 1973, 1977, 1980 and 1983; by the Committee on Scholarly Communication with the People's Republic of China, National Academy of Sciences, in 1980 and
1985; by the University of Michigan Museum of Anthropology Field Research Fund in 1984 , 1985, 1986, and 1988; by the L.S.B. Leakey Foundation in 1986; by Diana Blaban Holt in 1987; and by the National Science Foundation, grant BNS-8616298, in 1987. Essential assistance has also been provided by G. Brace of Nanterre, France; by M.L. Brace and Roger C. and Peggy L. Brace of Ann Arbor, Michigan; by J.K. Deetz of Berkeley, California; by Professors Ben R. Finney and Wilhelm G. Solheim, II, University of Hawaii; by Mark A. Gordon and Chacma, Inc., New York, New York; by Professor William W. Howells, Harvard University; by Professors Raymond C. Kelly, Frank B. Livingstone, and Henry T. Wright, University of Michigan; by Dr. Pamela D. Raspe, University of Cambridge; by Dr. B. Holly Smith, Museum of Anthropology, University of Michigan; and by Professor Robert R. Sokal, State University of New York at Stony Brook. Important financial support was also provided by the late E.B. Hoagland and by the late Professor and Mrs. G.W. Brace. 


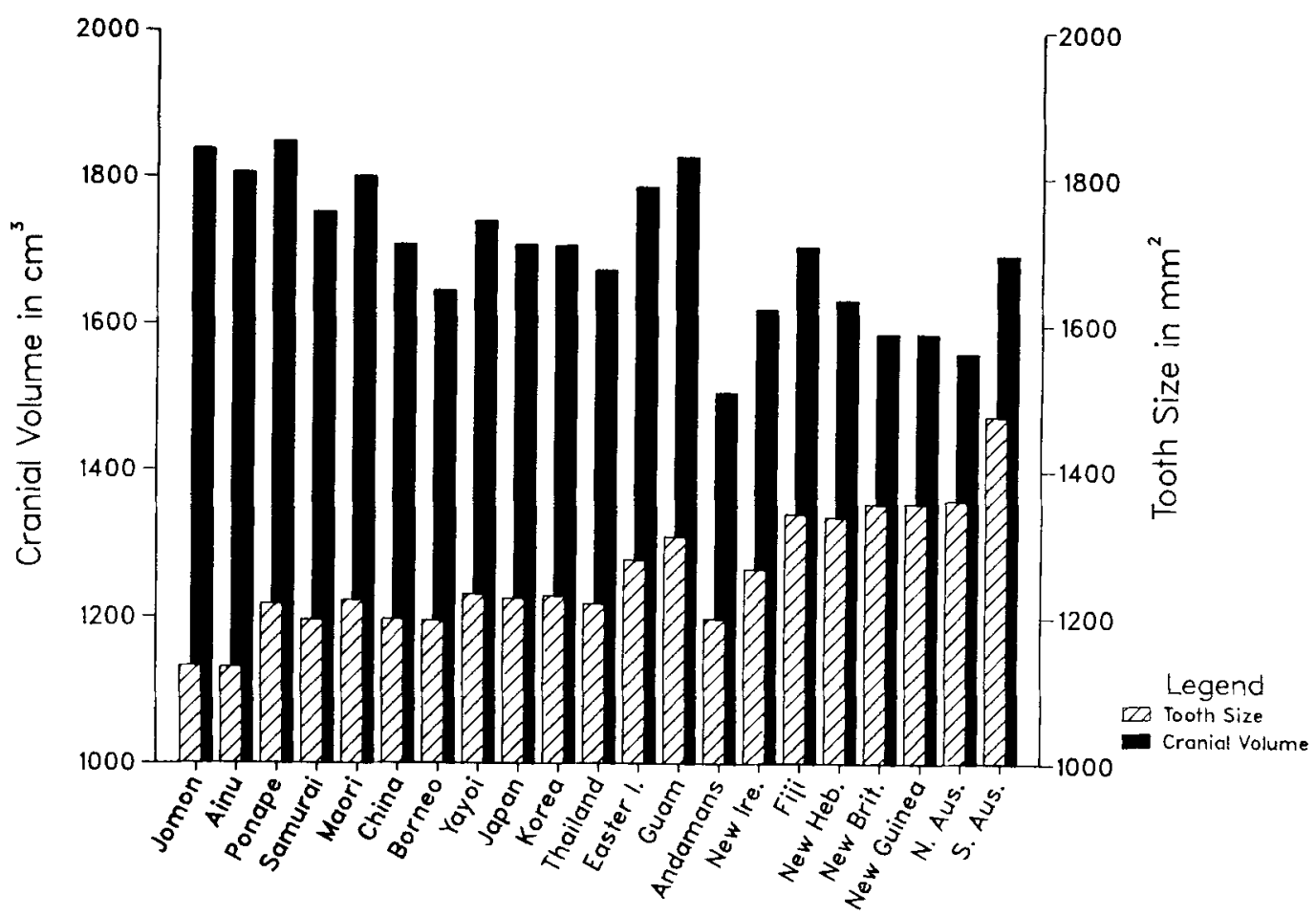

Fig. 8. Absolute tooth size and cranial volume figures for the same groups in the same order as that seen in Figure 7. Based on the data in Tables 3 and 4.

TABLE 3. Total tooth size (TS), cranial volume (CV), summed mesial-distal dimensions for maxillary P1-M3, nasion-basion figures, Flower's index, and the TS/CV index for a series of Asian and Pacific groups

\begin{tabular}{lcccccc}
\hline Population & Basion-nasion & $\begin{array}{c}\text { P1-M3 } \\
\text { Length }\end{array}$ & $\begin{array}{c}\text { Flower's } \\
\text { index }\end{array}$ & $\begin{array}{c}\text { Cranial } \\
\text { volume }\end{array}$ & $\begin{array}{c}\text { Tooth } \\
\text { size }\end{array}$ & $\begin{array}{c}\text { TS }^{1 / 2} / \text { cranial }^{1 / 3} \\
\text { volume }^{1 / 3}\end{array}$ \\
\hline Jömon & 102.90 & 40.60 & 39.5 & $1,838.1$ & $1,134.3$ & 27.5 \\
Ainu & 104.15 & 41.68 & 40.0 & $1,805.4$ & $1,132.3$ & 27.6 \\
Maori & 102.80 & 42.22 & 41.1 & $1,800.6$ & $1,223.0$ & 28.8 \\
Easter Island & 107.40 & 44.42 & 41.4 & $1,786.8$ & $1,278.6$ & 29.5 \\
Ponape & 103.00 & 43.13 & 41.9 & $1,848.2$ & $1,218.1$ & 28.4 \\
Samurai & 101.14 & 42.62 & 42.1 & $1,751.7$ & $1,196.5$ & 28.7 \\
Yayoi & 99.14 & 43.09 & 43.5 & $1,740.3$ & $1,231.4$ & 29.2 \\
Guam & 102.43 & 44.65 & 43.6 & $1,828.2$ & $1,310.9$ & 29.6 \\
Japan & 99.24 & 43.34 & 43.7 & $1,708.6$ & $1,225.8$ & 29.4 \\
Korea & 97.31 & 42.88 & 44.1 & $1,707.3$ & $1,229.3$ & 29.4 \\
China & 97.00 & 42.87 & 44.2 & $1,708.3$ & $1,197.3$ & 29.0 \\
Thailand & 95.81 & 43.22 & 45.1 & $1,673.7$ & $1,218.3$ & 29.4 \\
Borneo & 96.89 & 43.72 & 45.1 & $1,645.4$ & $1,195.9$ & 29.3 \\
Fiji & 99.52 & 45.57 & 45.8 & $1,706.1$ & $1,341.9$ & 30.6 \\
N. Australia & 99.13 & 45.64 & 46.0 & $1,560.8$ & $1,359.7$ & 31.8 \\
S. Australia & 100.98 & 46.67 & 46.2 & $1,694.2$ & $1,474.8$ & 32.2 \\
New Hebrides & 97.64 & 45.12 & 46.2 & $1,632.4$ & $1,337.6$ & 31.1 \\
New Guinea & 97.80 & 45.31 & 46.3 & $1,587.4$ & $1,356.0$ & 31.5 \\
New Britain & 98.39 & 45.77 & 46.5 & $1,587.3$ & $1,355.2$ & 31.5 \\
Andamans & 92.23 & 43.20 & 46.8 & $1,506.5$ & $1,198.5$ & 30.2 \\
New Ireland & 96.13 & 45.45 & 47.3 & $1,620.4$ & $1,266.0$ & 30.3 \\
\hline
\end{tabular}

For access to and help in the various collec- Panum Institute, University of Copenhagen; tions under their care, we are grateful to Dr. to Professor James J.F. Deetz, University of Verner Alexandersen and Dr. Pia Bennike, California, Berkeley; Professor Yukio Dodo, 
TABLE 4. Average and range of $N$ for the TS/Cranial Volume index

\begin{tabular}{lccr}
\hline & $\begin{array}{c}\text { Cranial } \\
\text { Polume }\end{array}$ & Range & Average \\
\cline { 3 - 4 } Population & 23 & $17-73$ & 49 \\
Jomon & 106 & $91-196$ & 137 \\
Ainu & 7 & $8-15$ & 11 \\
Ponape & 28 & $29-50$ & 42 \\
"Samurai" & 40 & $1-26$ & 9 \\
Maori & 227 & $25-234$ & 108 \\
China & 13 & $3-11$ & 6 \\
Borneo & 36 & $25-64$ & 48 \\
Yayoi & 331 & $153-305$ & 264 \\
Japan & 17 & $13-44$ & 22 \\
Korea & 82 & $50-75$ & 63 \\
Thailand & 15 & $1-21$ & 10 \\
Easter Island & 68 & $38-89$ & 70 \\
Guam & 27 & $1-19$ & 7 \\
Andaman Islands & 6 & $3-21$ & 8 \\
New Ireland & 7 & $2-5$ & 3 \\
Fiji & 14 & $3-14$ & 11 \\
New Hebrides & 71 & $13-67$ & 42 \\
New Britain & 15 & $2-11$ & 6 \\
New Guinea & 18 & $143-150$ & 149 \\
N. Australia & 21 & $164-338$ & 209 \\
S. Australia & & & \\
\hline & & & \\
\hline
\end{tabular}

Sapporo Medical College; Dr. James P. Garlick and Corinne Duhig, Cambridge University; Professor Kazuro Hanihara, University of Tokyo; Dr. Lean-Louis Heim, Musée de l'Homme, Paris; Dr. Per Holck, University of Oslo; Professor Jiro Ikeda, Kyoto University; Professor Toshihiro Ishii, Tohoku University; Professor Nina Jablonski, University of Hong Kong; Professor Li Yongyi, Chengdu College of Traditional Chinese Medicine; Professor Henry de Lumley, Institut de Paléontologie Humaine, Paris; Professor Masafumi Nagai, Kyushu University; Professor Yoshiatsu Naito, Nagasaki University; Professor Michael Pietrusewsky, University of Hawaii; Professor David Pilbeam, Harvard University; Professor George J. Romanes, University of Edinburgh Medical School; Professor Sood Sangvichien, Siriraj Hospital, Bankok; Professor Shao Xiangqing, Fudan University, Shanghai; Dr. Yoshihiko Sinoto, B.P. Bishop Museum, Honolulu; Dr. Christopher B. Stringer, British Museum, Natural History, London; Dr. Ian Tattersall, American Museum of Natural History, New York; and Professors Wu Jukang and Wu Xinzhi and Zhang Zhenbiao, Institute of Vertebrate Paleontology and Paleoanthropology, Academia Sinica, Beijing.

\section{LITERATURE CITED}

Allen J (1984) In search of the Lapita homeland. J. Pacific History 19(4):186-201.
Bellwood P (1975) The prehistory of Oceania. Curr. Anthropol. 16:9-28.

Bellwood P (1979) Man's Conquest of the Pacific: The Prehistory of Southeast Asia and Oceania. New York: Oxford University Press.

Bloch A (1909) Présentation de portraits des jeunes négresses pour faire voir la form particulière de l'aréole de la mamelle. Bull. Mem. Soc. Anthropol. Paris (V serie) 10:141-142.

Boyd WC (1950) Genetics and the Races of Man: An Introduction to Modern Physical Anthropology. Boston: Little, Brown and Co.

Brace CL (1964a) The concept of race. Curr. Anthropol. 5:313-320.

Brace CL (1964b) A nonracial approach towards the understanding of human diversity. In A Montagu (ed): The Concept of Race. New York: The Free Press of Glencoe, pp. 103-152.

Brace CL (1967) Environment, tooth form and size in the Pleistocene. J. Dent. Res., 46[Suppl]:809-816.

Brace CL (1977) Occlusion to the anthropological eye. In McNamara, JA (ed): The Biology of Occlusal Development. Craniofacial Growth Series Monograph No. 7 Ann Arbor, Michigan: Center for Human Growth and Development, pp. 179-209.

Brace CL (1978) Tooth reduction in the Orient. Asian Perspect. 19:203-219.

Brace CL (1979) Krapina "classic" Neanderthals, and the evolution of the European face. J. Hum. Evol. 8:527550.

Brace CL (1980) Australian tooth-size clines and the death of a stereotype. Curr. Anthropol. 21:141-164.

Brace CL (1982) The roots of the race concept in American physical anthropology. In F Spencer (ed): A History of American Physical Anthropology 1930-1980. New York: Academic Press, pp. 11-29.

Brace CL (1988) Punctuationism, cladistics and the legacy of medieval Neoplatonism. J. Hum. Evol. 3:121138.

Brace CL, Brace ML, Dodo Y, Hunt KD, Leonard WR, Li Y, Shao X-q, Sangvichien S, and Zhang Z-b Micronesians, Asians, Thais and relations: A craniofacial and odontometric perspective. J. Micrones. Soc. (in press a).

Brace CL, Brace ML, and Leonard WL (1989) Reflections on the face of Japan: A multivariate craniofacial and odontometric perspective. Am J. Phys. Anthropol. 78:93-113.

Brace CL, and Hinton RJ (1981) Oceanic tooth-size variation as a reflection of biological and cultural mixing. Curr. Anthropol. 22:549-569.

Brace CL, Li Y, Smith SL, Hunt KD, and Zhang Z-b A craniofacial comparison of circum-Pacific peoples. In DR Croes (ed): Circum-Pacific History Conference, Seattle, August 9, 1989. Pullman Washington, Washington State University Press (in press b).

Brace CL, and Mahler PE (1971) Post-Pleistocene changes in the human dentition. Am. J. Phys. Anthropol. 34:191-204.

Brace CL, and Nagai M (1982) Japanese tooth size, past and present. Am. J. Phys. Anthropol. 59:399-411.

Brace CL, Rosenberg KR, and Hunt KD (1987) Gradual change in human tooth size in the late Pleistocene and post Pleistocene. Evolution 41:705-720.

Brace CL, Shao X-q, and Zhang Z-b (1984) Prehistoric and modern tooth size in China. In FH Smith and F Spencer (eds): The Origins of Modern Humans: A World Survey of Fossil Evidence. New York: Alan R. Liss, Inc., pp. 485-516. 
Brace CL, Smith SL, and Hunt KD What big teeth you had Grandma! Human tooth size, past and present. In CS Larsen (ed): Advances in Dental Anthropology. New York: Alan R. Liss, Inc., in press c.

Brace CL, and Vitzthum VJ (1984) Human tooth size at Mesolithic, Neolithic and modern levels at Niah Cave, Sarawak: Comparison with other Asian populations. Sarawak Museum J. 33(54):75-82.

Cain AJ, and Harrison GA (1960) Phyletic weighting. Proc. Zool. Soc. London 135:1-31.

Cann RL (1988) DNA and human origins. Annual Review of Anthropology 17:127-143.

Cann RL, Stoneking M, and Wilson AC (1987) Mitochondrial DNA and human evolution. Nature 325:31-35.

Coon CS (1962) The Origin of Races. New York: Alfred A. Knopf.

Darwin CR (1859) On the Origin of Species by Means of Natural Selection, or the Preservation of the Favoured Races in the Struggle for Life. London: John Murray.

Dawkins R (1986) The Blind Watchmaker. New York: WW Norton.

Dobzhansky T (1944) On species and races of living and fossil man. Am. J. Phys. Anthropol. 2:251-265.

Excoffier L, and Langaney A (1989) Origin and differentiation of mitochondrial DNA. Am. J. Hum. Genet. 44:73-85.

Fagan BM (1987) The Great Journey: The Peopling of Ancient America. New York: Thames and Hudson.

Flower WH (1885) On the size of the teeth as a character of race. J. Anthropol. Inst. Great Britain Ireland 14:183-186.

Fox DJ, and Guire KE (1976) Documentation for MIDAS (3rd Ed). Ann Arbor: The Statistical Research Laboratory, University of Michigan.

Frayer DW (1978) Evolution of the Dentition in Upper Paleolithic and Mesolithic Europe. Lawrence, Kansas: University of Kansas Publications in Anthropology, No. 10.

Friedlaender JS, and Steinberg AG (1970) Anthropological significance of the gamma globulin (Gm and Inv) antigens in Bougainville Island, Melanesia. Nature $23: 59-61$

Gingerich PD (1974) Size variability of the teeth in living mammals and the diagnosis of closely related sympatric fossil species. J. Paleontol. 48:895-903.

Gingerich PD (1979) The stratophenetic approach to phylogeny reconstruction in vertebrate paleonotology. In J Cracraft and N Eldredge (eds): Phylogenetic Analysis and Paleontology. New York: Columbia University Press, pp. 41-77.

Gingerich PD (1980) Evolutionary patterns in early Cenozoic mammals. Annu. Rev. Earth Planet Sci. $8: 407-424$.

Gingerich PD, and Schoeninger MJ (1979) Patterns of tooth size variability in the dentition of primates. Am. J. Phys. Anthropol. 51:457-466.

Glass B, Sacks MS, Jahn EF, and Hess C (1952) Genetic drift in a religious isolate: An analysis of the causes of variation in blood groups and other gene frequencies in a small population. Am. Nat. 86:145-160.

Gould SJ, and Lewontin RC (1979) The spandrels of San Marco and the Panglossian paradigm: A critique of the adaptationist programme. Proc. R. Soc. London [Biol.] 205:581-598

Green R. (1973) Lapita pottery and the origins of Polynesian culture. Aust. Nat. Hist. June pp. 332-337.

Green RC (1986) Some basic components of the ancestral Polynesian settlement system: building blocks for more complex Polynesian societies. In PV Kirch (ed): Island Societies: Archaeological Approaches to Evolu- tion and Transformation. Cambridge: Cambridge University Press, pp. 51-54.

Groube L, Chappell J, Muke J, and Price D (1986) A 40,000 year old human occupation site at Huon Peninsula, Papua New Guinea. Nature 324:453-455.

Harding RM, and Sokal RR (1988) Classification of the European language families by genetic distances. Proc. Natl. Acad. Sci. USA 85:9370-9372.

Haynes CV Jr (1988) Geofacts and fancy. Nat Hist. 97(2):4-12.

Heim J-L (1976) Les Hommes Fossiles de La Ferrassie. Tome I. Le Gisement. Les Squelettes Adultes (Crâne et Squelette du Tronc). Paris: Masson. Archives de l'Institut de Paléontologie Humaine, Mémoire 35.

Hoerschelmann E (1904) Über die form der Mamma bei der Estin, mit Bemerkungen über die Mammaform bei einigen anderen Völkerschaften Z. Morphol. Anthropol. 7:22-62

Holl H (1920a) Über ein merkwürdige Verhalten der Brüste bei einer Buschmannfrau. Mitteilungen Anthropol. Gesellschaft Wien 50:7-10.

Holl $\mathrm{H}(1920 \mathrm{~b})$ Über den Abstand der Brustwarzen voneinander und die Sinusbreite beim weiblichen Geschlecht. Mitteilungen Anthropol. Gesellschaft Wien $50: 11-22$

Hooton EA (1918) Some early drawings of Hottentot women. Harvard Afr. Stud. (Varia Africana II) 2:83 99

Hooton EA (1926) Methods of racial analysis. Science $63: 75-81$

Hooton EA (1931) Up From the Ape. New York: Macmillan Co.

Hooton EA (1946) Up From the Ape (2nd Ed). New York: Macmillan Co

Howells WW (1973) Cranial Variation in Man: A Study by Multivariate Analysis of Patterns of Difference among Recent Human Populations. Papers of the Peabody Museum of Archaeology and Ethnology, Vol. 67. Cambridge: Harvard University Press.

Howells WW (1986) Physical anthropology of the prehistoric Japanese. In RJ Pearson, GL Barnes, and KL Hutterer (eds): Windows on the Japanese Past: Studies in Archaeology and Prehistory. Ann Arbor: Center for Japanese Studies, pp. 85-99.

Ikawa-Smith F (1980) Current issues in Japanese Archaeology. Am. Sci. 68:134-145.

Irving WN (1985) Context and chronology of early man in the Americas. Annu. Rev. Anthropol. 14:529-555.

Jennings JD (ed) (1979) The Prehistory of Polynesia. Cambridge: Harvard University Press.

Kirch PV, Swindler DR, and Turner CG II (1989) Human skeletal and dental remains from Lapita sites (1600 500 BC) in the Mussau Islands, Melanesia. Am. J. Phys. Anthropol. 79:63-76.

Koganei Y (1903) Über die Urbewohner von Japan. Globus 84(7):101-106.

Koganei Y (1927) Zur Frage der Abstammung der Aino und ihre Verwandtschaft mit anderen Völkern. Anthrop. Anzeiger 4(3):201-207.

Lack D (1961) Darwin's Finches. New York: Harper Torchbooks.

Lande R (1979) Quantitative genetic analysis of multivariate evolution, applied to brain:body size allometry. Evolution 33:402-416.

Lipiez M (1907) Über ein Schema zur Bestimmung der Brustform. Korrespondenz-Blatt Deutsch. Gesellschaft Anthropol. Ethnol. Urgeschichte 38(8): 175-180.

Livingstone FB (1958) Anthropological implications of 
sickle cell gene distribution in West Africa. Am. Anthropol. 60:533-562.

Livingstone FB (1962) On the non-existence of human races. Curr. Anthropol. 3:279.

Livingstone FB Who gave whom hemoglobin S: The use of restriction site haplotype variation for the interpretation of the B-globin gene. Am. J. Hum. Biol. (in press).

McKenna MC (1987) Molecular and morphological analysis of high-level mammalian interrelationships. In C Patterson (ed): Molecules and Morphology. New York: Cambridge University Press, pp. 55-93.

Marks J (1988) DNA hybridization: holy grail or golden calf? Am. J. Phys. Anthropol. 75:245-246.

Marks J, Schmid CW, and Sarich VM (1988) DNA hybridization as a guide to phylogeny relations of the hominoidea. J. Hum. Evol, 17:769-786.

Martin R (1928a) Lehrbuch der Anthropologie in Systematischer Darstellung, Vol. 1, Somatologie (2nd Ed). Jena: Gustav Fischer.

Martin R (1928b) Lehrbuch der Anthropologie in Systematischer Darstellung, Vol. 2, Kraniologie, Osteologie (2nd Ed). Jena: Gustav Fischer.

Martin RD (1983) Human Brain Evolution in an Ecological Context. New York: American Museum of Natural History.

Martin RD, and Harvey PH (1985) Brain size allometry: ontogeny and phylogeny. In WL Jungers (ed): Size and Scaling in Primate Biology. New York: Plenum, pp. 21-32.

Mayr E (1965) Numerical phenetics and taxonomic theory. Syst. Zool. 14(2):73-97.

Mercier CFX (1873) Eloge du sein des femmes (4th Ed). Paris: A. Barraud.

Morton NE, and Lalouel JM (1973) Bioassay of kinship in Micronesia. Am. J. Phys. Anthrop. 38:709-719.

Neel JV (1970) Lessons from a "primitive" people. Science 170:815-822.

Nei M (1983) Genetic polymorphism and the role of mutation in evolution. In M Nei and RK Koehn (eds): Evolution of Genes and Proteins. Sunderland, Massachusetts: Sinauer Associates, Inc., pp. 165-190.

Nei M (1987) Molecular Evolutionary Genetics. New York: Columbia University Press.

O'Brien SJ (1987) The ancestry of the giant panda. Sci. Am. 257(5):102-107.

Ohno S (1970) Evolution by Gene Duplication. New York: Springer-Verlag.

Pearce RH, and Barbetti M (1981) A 38,000-year-old archaeological site at Upper Swan, Western, Australia. Archaeol. Oceania 16(3):173-178.

Pearson K (1926) On the reconstruction of cranial capacity from external measurements. Man 27:46-50.

Pearson RJ (1986) Introduction to The Jömon, in Part III: Prehistory, culture history and society. In RJ Pearson, GL Barnes, and KL Hutterer (eds): Windows on the Japanese Past: Studies in Archaeology and Prehistory. Ann Arbor: Center for Japanese Studies, pp. 219-221

Ploss $H$ (1872) Die ethnographischen Merkmale der Frauenbrust. Arch. Anthropol. 5:215-220.

Ploss H, and Bartels M (1899) Das Weib in der Naturund Volkerkunde: Anthropologische Studien (6th Ed) Leipzig: Grieben's Verlag.

Ploss H, Bartels M, Bartels P, and Dingwall EJ (1938) Woman: An Historical Gynaecological and Anthropological Compendium. St. Louis: CV Mosby.

Renfrew C (1987) Archaeology and Language: The Puzzle of Indo-European Origins. London: Jonathan Cape. Riska B, and Atchley WR (1985) Genetics of growth predict patterns of brain-size evolution. Science 229:668-671.

Rothe F (1912) Untersuchungen über die Brüste von tausend norddeutschen Frauen und Mädchen. Luckenwalde: FCE Richten.

Rushton JP (1985) Differential K theory: The sociobiology of individual and group differences. Person. Individ. Differ. 6:441-452.

Rushton JP (1987) Toward a theory of human multiple birthing: Sociobiology and $r / \mathrm{K}$ reproductive strategies. Acta Genet. Med. Gemellol. 36:289-296.

Rushton JP (1988) Do $r / K$ reproductive strategies apply to human differences? Soc. Biol. 35:337-340.

Sarasin F (1924) Sur les relations des Néo-Calédoniens avec le groupe de l'Homo neanderthalensis. Anthropologie 34:193-227.

Schwidetzky I, and Rösing FW (1984) Vergleichendstatistische Untersuchungen zur Anthropologie der Neuzeit (nach 1500). Homo 35:1-49.

Schwartz JH (1984) The evolutionary relationships of man and orang-utans. Nature 308:501-505.

Sibley CG, and Ahlquist JE (1983) Phylogeny and classification of birds based on the data of DNA-DNA hybridization. In RF Johnston (ed): Current Ornithology, Vol. 1. New York: Plenum Press, pp. 245-252.

Sibley CG, and Ahlquist JE (1986) Reconstructing bird phylogeny by comparing DNA's. Sci. Am. 254(2): 82-92.

Sibley CG, and Ahlquist JE (1987a) Avian phylogeny reconstructed from comparisons of the genetic material DNA. In C Patterson (ed): Molecules and Morphology. Cambridge: Cambridge University Press, pp. 95-121.

Sibley CG, and Ahlquist JE (1987b) DNA hybridization evidence of hominoid phylogeny: results from an expanded data set. J. Mol. Evol. 26:99-121.

Smouse PE, and Li W-H (1987) Likelihood analysis of mitochondrial restriction-cleavage patterns for the human-chimpanzee-gorilla trichotomy. Evolution 41 : 1162-1176.

Smouse PE, Spielman RS, and Park MH (1982) Multiplelocus allocation of individuals to groups as a function of the genetic variation within and differences among human populations. Am. Nat. 119:445-463.

Sneath PHA and Sokal RR (1973) Numerical Taxonomy. The Principles and Practice of Numerical Classification. San Francisco: WH Freeman and Co.

Sokal RR (1965) Statistical methods in systematics. Biol. Rev. 40:337-391.

Sokal RR (1966) Numerical taxonomy. Sci. Am. 215(6):106-116.

Sokal RR, and Camin JH (1965) The two taxonomies: areas of agreement and of conflict. Syst. Zool. 14:176195.

Sokal RR, Camin JH, Rohlf FJ, and Sneath PHA (1965) Numerical taxonomy: Some points of view. Syst. Zool. 14:237-243.

Sokal RR, Oden NL, and Thomson BA (1988) Genetic changes across language boundaries in Europe. Am. J. Phys. Anthropol. 76:337-361.

Sokal RR, and Rohlf FJ (1969) Biometry: The Principles and Practice of Statistics in Biological Research. San Francisco: WH Freeman and Co.

Sokal RR, and Sneath HA (1963) Principles of Numerical Taxonomy. San Francisco: WH Freeman and Co.

Sokal RR, and Uytterschaut H (1987) Cranial variation in European populations: A spatial autocorrelation study at three time periods. Am. J. Phys. Anthropol. 74:21-38.

Sokal RR, Uytterschaut H, Rösing F, and Schwidetzky I 
(1987) A classification of European skulls from three time periods. Am. J. Phys. Anthropol. 74:1-20.

Solheim WG(1964) Pottery and the Malayo-Polynesians. Curr. Anthropol. 5:360, 376-384, 400-403.

Solheim WG (1972) Prehistoric pottery of Southeast Asia. In N Barnard (ed): Early Chinese Art and its Possible Influence in the Pacific Basin. New York: Intercultural Arts Press, pp. 508-532.

Solheim WG (1976) Reflection on the new data of Southeast Asian prehistory: Austronesian origin and consequence. Asian Perspect. 18(2):146-160.

Spielman RS, and Smouse PE (1976) Multivariate classification of human populations I. Allocation of Yanomama Indians to villages. Am. J. Hum. Genet. 28:317-331.

Spoehr A (1973) Zamboanga and Sulu: An Archeological Approach to Ethnic Diversity. Ethnology Monographs Number One. Pittsburgh: Department of Anthropology, University of Pittsburgh.

Spuhler JN (1988) Evolution of mitochondrial DNA in monkeys, apes, and humans. Yrbk. Phys. Anthropol. $31: 15-48$.

Spuhler JN (1989) Evolution of mitochondrial DNA in human and other organisms. Am. J. Hum. Biol. 1(5):509-528.

Stratz CH (1898) Die Schönheit des weiblichen Körpers. Stuttgart: Ferdinand Enke.

Stratz CH (1901) Die Rassenschönheit. Stuttgart: Ferdinand Enke.

Suzuki H (1970) The skull of the Amud man. In H Suzuki and F Takai (eds): The Amud Man and His Cave Site. Tokyo: University of Tokyo Press, pp. 123-206.

Suzuki H (1981) Racial history of the Japanese. In I Schwidetzky (ed): Asien I: Japan, Indonesien, Ozeanien. München: R. Oldenbourg Verlag, pp. 7-69.

Suzuki H, and Hanihara K (eds) (1982) The Minatogawa Man: The Upper Pleistocene Man from the Island of Okinawa. The University Museum, The University of Tokyo, Bulletin No. 19.
Terrell J (1986) Prehistory in the Pacific Islands: A Study of Variation in Language, Customs, and Human Biology. New York: Cambridge University Press.

Trinkaus E (1983) The Shanidar Neandertals. New York: Academic Press.

Turner CG II (1976) Dental evidence on the origins of the Ainu and Japanese. Science 193:911-913.

Turner CG II (1983) The origin of the Ainu. Review of H Suzuki and K Hanihara (eds): Minatogawa Man: The Upper Pleistocene Man from the Island of Okinawa. Quart. Rev. Archaeol. 4(2):11-12.

Turner CG II (1986) Dentochronological separation estimates for Pacific rim populations. Science 232: 1140-1142.

Turner CG II (1987) Late Pleistocene and Holocene population history of East Asia based on dental varia. tion. Am. J. Phys. Anthropol. 73:305-321.

Turner CG II (1989) Teeth and prehistory in Asia. Sci. Am. 206(2):88-96.

Turner CG II Origin and affinity of the people of Guam: A dental anthropological assessment. Micronesica (in press).

Verworn M, Bonnet R, and Steinmann G (1919) Der diluviale Menschenfund von Obercassel bei Bonn. Wiesbaden: JF Bergmann.

Wagner K (1937) The craniology of the Oceanic races. Skrifter Utgitt Av Det Norske Videnskaps-Akademi I Oslo, I. Matematisk-Naturvidenskapelig Klasse 2: 1-193.

Wallace DC, Garrison K, and Knowler WC (1985) Dramatic founder effects in Amerindian mitochondrial DNAs. Am. J. Phys. Anthropol. 68:149-155.

Weiss ML (1987) Nucleic acid evidence bearing on hominoid relationships. Yrbk. Phys. Anthropol. 30:41-73.

Witkowski GJ (1907) Les seins à l'église. Paris: A. Ma!oine.

Woo TL, and Morant GM (1934) A biometric study of the "flatness" of the facial skeleton in man. Biometrika $26: 196-250$. 